\title{
Using Cultural Artifacts, Positions, and Titles as Retentions of Cultural Attachments to Original Homelands: African Immigrants in the Diaspora
}

\author{
Michael Baffoe, Ph. D \\ Associate Professor of Social Work \\ Faculty of Social Work, 500B Tier Building \\ University of Manitoba, Winnipeg, MB R3T 2N2, Canada \\ Tel: 204-474-9682 e-mail: Michael.Baffoe@ad.umanitoba.ca \\ Lewis Asimeng-Boahene, Ph. D \\ Associate Professor of Social Studies Education \\ Penn State University, 777 Harrisburg Pike Harrisburg, PA 17057, USA \\ Tel: 717-948-6348 e-mail: lab45@psu.edu
}

Doi:10.5901/ajis.2013.v2n2p85

\begin{abstract}
The things to which we are connected benefit us to characterize who we are, who we were, and who we hope to become. These meanings are likely to be especially salient to those in identity transitions and play an important roles in the (re) construction of identities of immigrants like the African immigrants in the diaspora. In this paper, using critical race theory as our theoretical framework, we examine cultural artifacts like, traditional cloths, drums, sculptures, paintings as retentions of cultural attachments to the original homelands. You can take an African out of Africa, but you can never take Africa out of an African.
\end{abstract}

Keywords : Culture; cultural artifacts; Africans; immigrants; diaspora;identity construction; positions;titles

\section{Introduction}

The decades since the 1960s (marking the beginning of the post-colonial era in Africa) have seen the acceleration of African immigrant populations settling in Europe and the United States and the emergence of new African diaspora communities and trans-national expressive culture (N'Diaye, 2004). First generation, new diaspora immigrants often choose to draw on the community expressive culture of their homelands to shape their group identities in their host country. Through actively creating and re-creating practicing and performing traditions from home, both among community members and in public settings, they use tradition as a tools to build community. They emphasise aspects of culture that serve them in this effort while choosing to discard other aspects that do not fit the context of the host country. African immigrants actively and consciously attempt to recreate culture in a new place with the goal of maintaining cultural connections between their original homeland in Africa, themselves and their children born in the diaspora.

Cultural context, according to Lee, Spencer and Harpalani (2003), is often neglected in the study of human development and education. This, ironically, seems very true about research on ethnic minorities and even more so for research about Africans in the diaspora, a relatively new population group in North America. In their attempts to reconstruct their place in their new societies, Africans in the diaspora engage in a process of cultural socialization, which is defined as "how people learn to live culturally" (p. 7).

\section{Cultural artifact}

A cultural artifact is a term used in the social sciences, particularly anthropology, ethnology, and sociology for anything created by humans which gives information about the culture of its creator and users. It is human-made, may change over time in what it represents, how it appears and how and why it is used as the culture changes over time.

Usage of this term encompasses the type of archaeological artifact which is recovered at archeological sites: however, current objects of modern or near-modern society are also cultural artifact. Cultural artifacts can provide 
knowledge about technological processes, economy and social make up, and a host of other subjects (*http://:en.wikipedia.org/wiki/Cultural artifacts). In other words, cultural artifact could be an object made or shaped by human hand; an object, such as a tool, weapon or ornament, of archaeological or historical interest (en.wiktionary.org/wiki/ artifact).

The goal of this article is to examine African cultural artifacts as retentions of cultural attachments to the original homelands of African immigrants in the diaspora. We begin with a discussion of the characteristics of African immigrants in the diaspora. We then offer critical race theory (CRT) as theoretical framework guided by our mantra that you can take an African out of Africa, but can never take Africa out of an African, to support the use of cultural artifacts as retentions of cultural attachments to the original homelands by African immigrants in the diaspora. Next, we address the African cultural artifacts like, traditional cloths, drums, sculptures, and paintings. We then highlight rites of passage including funerals, child naming, festivals, chieftaincy and leadership as features of retentions of cultural attachments to the original homelands. We conclude with an observation that Africans in the diaspora continue to hold on to and strongly display attachments to their cultures and cultural artifacts as a strong counter-story telling effort in new homelands where they see themselves as minorities whose cultures are regarded as insignificant. They see their counter-story telling as a way of maintaining or preserving their cultures and passing them down to their children.

\section{Characteristics of African immigrants in the diaspora}

This is a fluid question which has engaged scholars with different ideological persuasions. According to Saffrans (1991) the concept could be applied to members (Africans) of "expatriate minority communities" who share the following characteristics:

They are, or their ancestors, have been dispersed from a specific original "center' (in Africa) to two or more "peripheral," or foreign, regions. They retain a collective memory, vision, or myth about their original homeland-its physical location, history, and achievements; they believe that they are not---and perhaps cannot be ---fully accepted by their host society and therefore feel partly alienated and insulated from it.

Africans in the diaspora regard their ancestral homeland as their true, ideal home and as the place to which they should collectively, be committed to the maintenance or restoration of their original homeland and to its safety and prosperity.

They continue to relate, personally or vicariously, to that homeland in one way or another, and their ethnocommunal consciousness and solidarity are importantly defined by the existence of such a relationship. The extent to which these African diaporans are committed to their original homelands is underscored by the length to which many of them go to ensure that on their death in their diaporan homes, the bodies of their loved ones, and themselves, are returned to their ancestral lands in Africa for burial (Odhiambo 1992, Sarpong, 1974).

African immigrants in this article, refer to recent immigrants to the places outside the African continent, especially Europe, North America and Australia during their life time within the last few decades) and their children. This group is to be distinguished from Afro-Americans who are descended from Black Africans who survived the slavery era within the boundaries of the present United States, as well as Americans with roots in other parts of the African Diaspora such as the Caribbean. In other words, the term encompasses individuals of recent African ancestry. "African", in the scope of this article therefore refers to national origins rather than racial affiliation as defined by the United States Census.

Fifty Africans in the diaspora from ten cities in the United States and Canada were selected through simple random sampling for this study. All participants gave their consent to participate in the study.

\section{Theoretical Framework}

The theoretical framework used to examine and analyze our research was based on Critical Race Theory (CRT). We utilized CRT as a theoretical anchor because though rooted in legal analysis, CRT insists on recognition of the experiential knowledge of people of color/marginalized (Diasporans) and their communities of origins in analyzing society (Delgado, 1995, Degaldo \& Stefancic, 2001). In effect, CRT gives voice to the marginalized peoples to tell their stories and experiences within a theoretical framework where the center of analysis is the narrative. CRT seeks empowerment for the marginalized by using their needs and culture to support empowering conditions (Grant \& Asimeng-Boahene, 2006). This theoretical framework was also of interest to us in our study because it specifically involves the following among its five significant tenets: counter-story telling and interest convergence (DeCuir \& Dixson, 2004). Other tenets of 
critical race theory, according to (DeCuir \& Dixson, 2004) are: the permanence of racism, (Bell, 1992), Whiteness as property Harris, (1995) and the critique of liberalism.

The paper is also conceptually housed in social justice paradigm as social justice could be seen as a way of recognizing, respecting, and valuing differences in race, cultural beliefs, social norms, intellectual flexibility, and personal perspectives and dispositions. Also social justice recognizes appreciating diversity, promoting equity, advancing broadmindedness, and encouraging voice and expression (Brooks \& Thompson, 2005). As Crenshaw (1995) also points out succintincly, critical race theory has an activist aspect, the end goal is to bring change that will implement social justice. Thus, the use of cultural artifacts by the people in the diaspora can serve as a means of elucidating their stories and experiences which are not often told as they tend to be at the margins of the chosen countries. Sleeter\& Bernal (1995) point out that Critical Race Theory is similar to antiracist education because "it is a social justice paradigm that seeks to combat racism as part of a larger goal of ending all forms of subordination" (p. 246).

As will be shown in this article, the participants in this study, Africans in the diaspora, seek to showcase their culture in activist roles aimed at achieving a form of social justice: the recognition of the importance of their cultures by the mainstream societies in their new homelands.

Delgado (1989) reminds us that "oppressed groups have known instinctively that stories [which can take different forms] are an essential tool to their own survival and liberation" (p. 2346). Consequently, the counter story which takes the form of the use of cultural artifacts can, therefore, serve as a tool for exploring, analyzing, and questioning the mainstream stories of racial privilege.

The African ideology of Sankofa (going back to one's roots), is another significant aspect of African tradition which has often been cited as a special feature of Blackness and Africanness (Assimeng, 1997). It is another methodological framework upon which this study is anchored. "It is significant that in the current search for new political, economic, and cultural structures in Africa, a return to the past has become a popular calling" (p.89). From this angle therefore, tradition has been seen as the embodiment of all that is beautiful, valuable, and vital in African social structure. Thus African tradition, which its people in the diaspora are struggling to uphold and project in their new homelands can scarcely be ignored in current social analysis. Every group of people, throughout history, has taken pride in creating the impression that it too, has (has had) certain unique contribution to make towards civilization. Africans in the diaspora are no exception to this phenomenon. Thus, it is our attempt, in this paper, to shed light on the attempts by Africans in the diaspora to salvage their cultural honor by revisiting or returning to their past (their countries and cultures of origin) where socio-economic and cultural ways are appreciated, respected and adored. This underscores our proposition that you can take the African out of Africa, but you cannot take Africa out of the African.

The issues we unearthed about African immigrants in the diaspora are therefore about using cultural artifacts to tell their own stories, from their own point of view. These are groups of people whose interest converge in new places that they now call "home" far away from their original homelands They use similar symbols in the form of artifacts to tell their stories or to show attachments to their original homelands. The showcasing of African cultural artifacts by Africans in the diaspora, as Degaldo\&Stefancic, (2001) put it, is therefore a form of counter-story telling that allows for the challenging of privileged discourses, "the discourse of the majority, therefore, serving as a means for giving voice to marginalized groups" (p. 41).

In other words, counter-story telling "helps us understand what life is like for others, and invite the reader (or outsider) into a new and unfamiliar world" (p.41). Some participants in this study from the Eastern Canadian City of Montreal, originally from Ghana in West Africa recall how the local police used to describe the Ghanaian men as the "blanket people", a reference to their traditional cloth which is a full one piece of cloth wrapped around their bodies which they mostly wear for their public, community, church events and other cultural events.

There are so many forms of African cultural artifacts. For the purpose of this study we focused on sculptures, paintings and traditional dresses since these are the ones mostly used by Africans in the diaspora in showcasing their cultures.

\section{African sculptures}

African sculpture varies widely with location. Each region has a unique style and meaning to their sculptures. The type of material and purpose for the sculpture reflects that of the region of creation. African sculptures have social, spiritual and political significance:They are sometimes used to transmit the laws, moral codes, and history to the young.Some serve to facilitate communication between people and supernatural forces and beings.Some do have religious and social 
undertone, e.g., the Ghanaian fertility doll. These sculptures are apparently devoted to fertility in their representation of the true human form.Masks may often are used for ceremonial purposes. They are also made to indicate the wealth and status of its owner.

In sum, being aesthetically pleasing, their beauty and their content combine to make African Sculptures the vehicle that ensures the survival of traditions, protects the community and the individual, and tells much of the person or persons who use them or to whom they refer (http://www.africa.upenn.edu/sculptures)

\section{African paintings}

African paintings bring color and style to the home. The art forms are varied and range from photographic realism through to the very abstract. African paintings have social, spiritual and political significance.Human figures in African painting could symbolize both the living and the dead. They could represent chieftains, dancers, and other numerous types.

African immigrants in the diaspora are found of maintaining the significance, meaning and place of sculpture in African traditions. They decorate their homes in the diaspora with various African sculptures and paintings depicting their beliefs and underscoring their retentions, memories and attachments to the original homelands. All the participants interviewed for this study admitted having a number of African sculptures and paintings in their homes and offices in their places of sojourn in the diaspora. Most of them said they bought these artifacts from their original homelands whenever they visited. Others bought them from African Art shops in their diasporan cities. We visited the homes of some of the participants as well as a number of African Community Centers (places where the African community members routinely congregate to hang out or celebrate occasions) in some of the cities where the research participants live. All the Centers and homes we visited were decorated with various African sculptures depicting their various beliefs and significance.

\section{African cloths/dresses}

Traditional African clothing represents different regions' natural resources and agricultural practices. The idea of African clothing inspires images of rich colors and ceremonial dress but, the fact is, African clothing is as diverse as the African continent. Africa's ancient civilizations demonstrate the continent's long history of creating clothing for utilitarian as well as celebratory and symbolic purposes. Despite its many variations, there are several unifying features of and facts about African clothing (Makofsky, n.d).

There are countless types of African clothing, but some styles that stand out for their popularity or their symbolic significance include dashikis, brightly printed tunics that became popular in the United States during the Black Power movement; embroidered Yoruba asooke, (Nigeria) worn for celebrations; and princess kaftans, which usually are printed in intricate patterns. For men, a standout African ensemble consists of a four-piece coordinated Babarigaoutfit featuring a hat, long-sleeved shirt, AgbadaBubu (sort of like a flowing cape) and pants.

\section{Features}

Some of the classic features of African clothing pertain to its colors and prints. Patterns may be created by tie-dye or batik, a method of applying wax to fabric before dying it. Embroidery, brocade and beading are common ornamentation. For special occasion or expensive clothing, people still hand-weave the fabric, using traditional looms.

\subsection{Kente:}

Perhaps the most popular of all African clothing is the Kente. To its users in most parts of West Africa, Kente is more than a cloth. For instance, the Asantes of Ghana refer to Kente as nwontoma, (hand-woven cloth) to distinguish it from the factory-made cloth (ntoma).

\subsubsection{Significance of Kente cloth.}

Kente has political, social and economic significance. Kente is the best known and most widely appreciated of all African textiles, adopted throughout the African diaspora worldwide since the 1960 s as a symbol of Pan-Africanism and Afrocentric identity. It has been used to inscribe forms of political commentary. Ghana presented a large piece of a specially- 
designed Kente cloth named "tikoronkoagyina" (one head does not constitute a council) to the United Nations in 1960. This was to highlight the collective decision-making structure of the United Nations and the new world order. Kente is worn by people of all social status. In the past, certain designs were specifically made to be worn by the royals. Later with the rising economic prosperity, non royals began to demand for what was worn by the royals. Thus there is a Kente cloth called W'anyawo ho a, wonyedehyee (you may be rich, but you are not of royal descent). In sum, African immigrants in the diaspora, value Kente as a cloth of status and see it as a generalized marker of identification with Africa, and as a symbol of empowerment, status symbol and entitlement (Kreamer, 1999).

Africans in the diaspora especially display a strong attachment to their traditional clothes especially Kente cloth as an outward, most visible display of their culture. It is common to see most African women in the disapora attending most functions especially church services in their traditional cloth. When it comes to other community events in the diaspora like celebrating national days of their original homelands, rites of passage like birth/naming ceremonies and funerals and other outdoor events, Africans in the diaspora are most likely to be dressed their traditional cloth. The West Africans especially display a strong attachment to, and public display of their traditional cloth for public and community events in the diaspora. The views from some of the participants in this study on the rational for their display and use of their traditional dresses in the diaspora are provided in the last section of this report.

\subsection{Ceremonies:}

There are different stages in life. These stages are called life cycle. They are birth, puberty, marriage, death and life after death. In Ghanaian traditional societies, rituals are performed to move a person from one stage of life to another. These rituals are called rites of passage. They may include birth ceremonies, naming ceremonies, and funerals (Nkrumah \& Whyte, 1999). This study focused on births, child naming and funerals as the rites of passage adhered to by Africans in the diaspora. We also looked at their adherence to festivals and installation of ethnic diasporan chiefs as another area in which they frequently showcased their cultural practices.

\subsubsection{Naming ceremonies}

In Africa, a range of social, religious and cultural circumstances heralds the birth of children and determines their naming (Skhosana, 2001). The birth of children signifies strong cultural and religious significance for African families. Children are regarded in most African societies as blessings from God (the Supreme Being, or the Ancestors). Very elaborate ceremonies are undertaken to celebrate the birth of children. In line with the significance attached to the birth of children, names bestowed on them at birth have definite meanings...hence, parents, relatives, neighbors are very careful when choosing the name of an individual. Ladzekpo (2001) notes that an African's personal name offers insight into one's cultural origin. It signifies the values, beliefs, convictions, traditions, hopes, fears, and conceptions of the particular ethnic group. Hence, a name is the identity of and window into one's culture and self.

Nkrumah \& Whyte (1999, p. 65) highlight the following as the significance of naming and naming ceremonies in African traditions: The ceremony is used towelcome the child formally into the world on the eight day by which timeit is regarded as a real human being. It is at the naming ceremony that the child if identified as an individual and a family member. It also marks the beginning of laying of foundation for good morals and values. He is named after a person with good morals, so that the baby will follow his footsteps.

Most Africans do not have a common family name. Children are given the surnames of their fathers for official purposes but on the eighth day after their birth, they are named after important personalities in the lives of their parents (usually the paternal heritage).

Examples of some popular African names are:

Fumilayo : Give me Joy (Yoruba, Nigeria)

Gbenga: God's Elevation (Yoruba, Nigeria)

Biodun: Born during festive period (Yoruba, Nigeria)

Chinedu: God's guidance (Ibo, Nigeria)

Nyamekye : God's Gift (Akan, Ghana)

Odhiambo: Male born in the evening (Kenya)

Akoth: Female born when raining (Kenya)

Naledi (Setswana) My Star(Botswana) 
In sum, as Madubuike (1976) remarks, "names are not merely labels or simple tags which the individual carries along with him. They have a deep social significance, and many names studied, collectively express a worldview, the weltanschauung of the people" (p. 13-14). Africans in the diaspora adhere strictly to these birth ceremonies and naming patterns. The African communities in the diaspora studied for this research all attach great significance to births and naming and joyous and elaborate ceremonies are undertaken for these rites of passage. The West Africans, especially Ghanaians in the disapora put up elaborate child outdooring ceremonies to showcase or present their new-born to their communities. They follow the same naming pattern as pertains in their original homeland.

Among the West Africans studied for this research, they will the newly-born a heritage name during the naming ceremony in the diaspora but on the official birth certificate, they will show a given name and the father's surname. When asked about the reason for this dual naming, the participants ascribed their attachments to their traditions and cultures for the practice. For example a male child born on a Friday to a Ghanaian family in the diaspora was named after his grandfather in the original homeland. His name announced on the community baby naming ceremony in then diaspora was Kofi (Friday male-born) Nyamekye (God's Gift), Nyamekye being the name of the grandfather. It was also announced at the same ceremony that his "official name" for school and "government documents" was Charles Owusu (the last name is that of the disaporan father). This underscores the strong attachments of these African diasporans to their original cultural practices regarding the rites of passage.

\section{Traditional Festivals}

Traditional festivals are occasions, and in most cases, annual celebrations at which rituals are performed to honor and give thanks to the spirit forces for their past favors and to make request from them for the future. Some festivals are agricultural because they are connected with fishing, farming or hunting and are celebrated before and after the agricultural season. Examples of agricultural festivals in West Africa are Homowo (the Gas of Ghana), Bakatue (the Fantis of Ghana), Egungun (the Yorubas of Nigeria), Aboakyer (the deer hunt festival of the Efutus of Ghana) etc. Some festivals are connected with the ancestral gods. Most of them are historical because they recount the deeds of the ancestors and link the people with their past. Both agricultural and ancestral festivals could be historical (Nkrumah and Whyte, 1999).

\subsection{Significance of African Traditional Festivals}

Nkrumah \& Whyte, (1999) also provide the following, among others, as the significance of traditional African festivals: It unites the people to resolve conflicts; they mark the beginning of the traditional year; helps the living to have contact with the spirit-forces and give thanks to them for their care and favour and preserves culture and promotes traditions. They are also used as occasions to remember and mourn the dead; help the people to renew their loyalties to their chiefs by paying homage to them; helps the youth to know their traditions and promote socialization and helps the youth choose their life partners. The chiefs and traditional priests "perform purificatory rituals, which strengthen their spirit and social life to be successful in the coming year" (p. 19-20).

Festivals also promote tourism. In modern times, festivals serve as platforms for the government (politicians) to educate people on governmental activities. The people also raise money through fund-raising activities during the festival celebrations to develop their communities.

Diasporan Africans re-enact some of the important festivals from their homelands in their new places of sojourn. We attended a number of these festivals in US and Canada: the Ghanaian community's Chicago Ghana Fest, Toronto's Odwira Festival and the Ghana Fest in New York City. It was refreshing to observe African cultural regalia and displays at their finest. These events involved long processions and sitting-in-state of local diasporan chiefs, queens and elders, outdooring of variety of cultural artifacts. Almost everyone among the thousands of revelers at these festivals who claim African origins wore African traditional clothing especially the kente cloth.

\subsection{Funerals}

Funerals play an important role in African society and life. They are conspicuous in part due to the prominent display of color of different cloths, head dresses and footwear, among others, during such ceremonies. The funeral day is a great day usually set aside by the family to mourn and remember the dead. In most places, the funeral day is different from the 
day of burial. There is wake keeping on the night before the funeral day. During this time, there is singing of traditional songs, dancing and firing of musketry. On the day of the funeral, close relatives sit together at a particular area where they can be recognized easily. They dress in either red, black or any dark-brown cloth or "adinkra" cloth. In Akan the surviving partners put on raffia around their elbows. It signifies that since the spouse is dead there is no one to depend on.

When sympathizers arrive on the funeral day, they go round and shake hands with members of the bereaved family. Every sympathizer donates to help pay for some of the funeral expenses. These donations are publicly announced (Nkrumah \& Whyte. 1999).According to Sarpong (1974, p. 29), the Ghanaian lays much store on the way in which his funeral or the funeral of his relative is observed. A 'bad' funeral is a disgrace as much to the dead person as it is to his living relatives. A 'good' funeral on the other hand is prestigious. Everybody speaks about it long after it has been observed. In many countries in Africa, Funeral Day is the day of burial. In Ghana particularly, the day of burial is not the funeral day. The funeral day is a day set apart to remember the deceased in a special manner.

From the color of the cloth worn too, one is able to deduce if a mourner is closely related to a deceased person or not. Funerals may seem to be too elaborate, they may appear to be ridiculously out of all proportion to other rites and ceremonies." Whatever one thinks of funerals, one must not tell the Ghanaian to abolish them. One might as well tell the Irish Bishop to forget about the Feast of St. Patrick" (Sarpong, 1974, p. 32).

Africans in the diaspora attach strong significance to funerals in their new homelands. We observed elaborate funeral ceremonies in the various African communities we studied in Canada and the United States. These funeral ceremonies were either for those that had died in the diaspora or for close relatives who had died "back home". All these funeral ceremonies were exact replicas of the ceremonies in their original homelands: the color of the mourning cloths, the funeral processions, singing of funeral dirges and presentations of drinks and donations. The participants interviewed for the study emphasized the fact that they owe a duty to their dead whether they passed away in the diaspora or "back home" to perform a "fitting" funeral. Some said the spirits of their parents especially will not forgive them if they performed a low-cost simple funeral ceremony on their death.

\subsection{Re-enactment of Positions and Titles}

For the purpose of this study, we focused on the re-enactment of the position of Chiefs and the use of chieftaincy titles as other aspects of African traditions and cultural practices frequently used by Africans in the diaspora. Chief refers to a person of eminence, a community leader or overlord. In Africa, the British used chief as a common term of reference for a variety of traditional leaders (Mamdani, 1996). In some societies (e.g., Asante, Dahomey, Buganda) women can hold positions of power parallel or even superior to male titleholders, but women are addressed not as chiefs but as queenmothers (Manu, 1988). Traditionally, African kings and chiefs invariably combine secular and ritual powers. Some have more mystical than secular functions, making the ruler a priest-king or a divine-king. In the past, chiefs played many roles. They were judges and maintained the rule of law. They served as military leaders and led in wars. They were the custodians of communal ideals and enacted rites and customs that sustained the moral and cultural values of society (Hagan. 2004).

In some cultures (e.g., the Igbo), the chief is a mere honorific title that one takes as a mark of personal achievement and outstanding generosity. The title must be "constantly validated to be retained" (Uchendu, 1965, p. 20), and no family has exclusive claim to any title.

Africans in the diaspora re-enact these cultural chieftaincy expositions as a way of retaining their strong cultural attachments to their original homelands. Many engage in fierce competition to assume chieftaincy titles and roles, albeit for their symbolic significance. The African diasporan chiefs exert no secular authority or "powers". However, once they are elected and assume such chieftaincy positions, their followers and community members accord them some form of respect and regard them as replicas of the traditional rulers in their original homelands.

The chieftaincy institutions and the strong attachment to them, is particularly strong among the Ghanaian Asante ethnic groups across North America. In all the communities surveyed for this study, the Asantes engage in the most elaborate chieftaincy installation ceremonies during which a number of cultural artifacts and regalia are displayed. Although the ascension to the chieftaincy positions were through elections instead of membership of royal families as pertains in their Ghanaian homeland, the diasporan chiefs took on the same chieftaincy titles, performed cultural ceremonies and presided over traditional festivals in the diaspora similar to such events in the original homelands. 
We attended and observed a number of cultural ceremonies in some of the communities we studied and we were amazed at the strong attachments the diasporans displayed towards these cultural displays. They all pointed to the need to retain their cultural heritage, and to pass it over to their children. Most importantly, and in line with the tenet of counterstory telling in Critical Race Theory, they regarded their adherence to these cultural displays as their way of showcasing and narrating the richness and beauty of their culture to mainstream North American society. "We need to tell our own cultural stories", they said. Below are some views from some of the study participants:

\section{Conclusion}

We have highlighted African cultural artifacts like drums, sculptures, paintings, cloth, ceremonies, positions and titles etc; and their socio-political, spiritual and economic significance. African immigrants may have scar tissues from their journeys to the Diaspora because of the lack of control they have over the production of their own identity within the majority populations in the Diaspora. However they want the world to note that their wounds will always define them...even in "homes" far away from the original "homes". The attachments to, and retentions of their cultural artifacts, serve as the transmission of values and the accumulated knowledge of their societies from the original homelands. This will continue to identify them as Africans. Yes, you can take the African out of Africa, but you can never take Africa out of the African.

\section{References}

Brooks, J., \& Thompson, E. (2005). Social Justice in the Classroom. Educational Leadership, 48-52.

DeCuir, J. T., \&Dixson, A. D. (2004). "So when it comes out, they aren't surprised that it is there": Using Critical Race Theory as Tools of Analysis of Race and Racism in

Education,Educational Researcher vol. 33 no. 5 June/July, 2004: American Educational Research Association.

Crenshaw, K. W. (1995). Mapping the margins: Intersectionality, identity politics, and violence against women of color. In K. Crenshaw, N. Gotanda, G. Peller, \& K. Thomas (eds).

Critical race theory: The Key writings that formed the movement (pp. 357-383). New York: The New Press.

Delgado, R. (1989). Story-telling for opportunists and others: A plea for narratives. Michigan Law Review, 87, pp.2411-2441.

Delgado, R. (1995). Towards a critical race theory: The cutting edge. Philadelkphia, PA: Temple University Press.

Delgado, R., \&Stefancic, J. (2001). Critical race theory: An introduction. New York: New York University Press.

Grant, R. A. Asimeng-Boahene, L (2006). Culturally responsive pedagogy in citizenship education: Using African proverbs as tools for teaching in urban schools. Multicultural Perspectives, 8(4), 17-24.

Ladzekpo, E. (2001). African personal names: Their historical and cultural significance. http://www.sol.city.(web project/introduction). Retrieved on December 21, 2009.

Maduike, I. (1976). A Handbook of African Names. Washington, D.C.: Three Continents Press.

Makofsy, N. (n.d). African Clothing Facts, eHow On-Line Magazine: http://www.ehow.com/about 5059443_african-clothing.htm Retrieved on January 24,2010

Mamdani, M. (1996). Citizen and Subject. Princeton: Princeton University Press.

Manu, T. (1988). The Asantehene's Court and its jurisdiction over women: A study in legal pluralism. Research Review 4(2), pp. 50-66.

McNaughton, P. R., \&Pelrine, D. (1995) African Art. In P. M. Martin \& P. O'Meara (eds.) Africa (3rd). London: James Currey.

N'Diaye, D. B. (2004). Diaspora: African communities in the United States. In P. M. Peek \& K.

Yanka (eds.). African Folklore : An Encyclopedia (pp. 85-87). New York: Routledge.

Nkrumah, E. B. \& Whyte, J. K. (1999). Do The Right Thing Series: Religious and Moral Education for J.S.S (rev. ed). Kumasi, Ghana: Brother James.

OdhiamboAtieno, E. S. (1992) Burying S.M.: The Politics of Knowledge and the Sociology of Power in Africa. James Currey and Heinemann.

Ramsey, F. J., \& Edge, W. (2004). Global studies: Africa (10th ed. Guilford, CT: McGraw-Hill/Dusking.

Saffran, W. (1991). Diasporas in modern societies: myths of homeland and return. Diaspora, 1, 83-91.

Sarpong, P. (1974). Ghana in retrospect:Some aspects of Ghanaian culture. Accra-Tema: Ghana Publishing Co.

Skhosana, P. B. (2001). Names and practices among southern Ndebele male persons. Nomina Africana 15, nos. 1 \& 2.

Sleeter, C. E. \& Bernal, D. D. (1995). Critical pedagogy, Critical race Theory, and Anatiracist Education: Implications for Multicultural Education. In banks, J. A \& Banks, C. A. M (eds) (1995). Handbook of Research on Multicultural Education. Jossey-Bass.

Uchendu, V. C. (1963). The Igbo of Southern Nigeria. New York, Holt, Rinehart and Winston. (*http:/l:en.wikipedia.org/wiki ICultural_artifacts) Retrieved: October 24, 2009.

http://www.africa. upenn.edu/sculptures. Retrieved on November 30, 2009 